\title{
A redescription of Chedima purpurea Simon, 1873, with notes on the unique copulative stopper mechanism in females (Aranei: Palpimanidae)
}

\section{Переописание Chedima purpurea Simon, 1873, с замечаниями об уникальном стопорном копумятивном механизме у самок (Aranei: Palpimanidae)}

\author{
Sergei L. Zonstein ${ }^{1}$, Yuri M. Marusik ${ }^{2,3,4}$

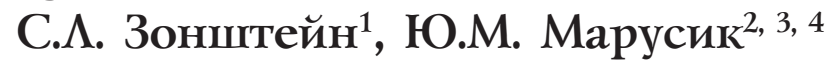

\footnotetext{
${ }^{1}$ Department of Zoology, Steinhardt Museum of Natural History, Tel-Aviv University, 69978 Tel-Aviv, Israel. E-mail: znn@post.tau.ac.il

${ }^{2}$ Institute for Biological Problems of the North RAS, Portovaya Str. 18, Magadan, 685000 Russia. E-mail: yurmar@mail.ru

${ }^{3}$ Department of Zoology \& Entomology, University of the Free State, Bloemfontein 9300, South Africa.

${ }^{4}$ Zoological Museum, Biodiversity Unit, FI-20014 University of Turku, Finland.

2 Институт Биологических проблем Севера, ДВО РАН, Портовая 18, Магадан 685000 Россия.
}

KEY WORDS: spiders, Araneae, Chediminae, taxonomy, redescription, postgastrum, mating plug, Africa, Morocco.

КЛЮЧЕВЫЕ СЛОВА: пауки, Araneae, таксономия, переописание, постгаструм, стопорный механизм, Африка, Марокко.

ABSTRACT. A monotypic Chedima Simon, 1873, the nominative genus of the subfamily Chediminae, and its type species C. purpurea Simon, 1873, are redescribed. The copulatory organs of $C$. purpurea are illustrated for the first time. The morphological study of the genus reveals several features previously unknown in the Palpimanidae, or in the Entelegynae, or even in the entire order Aranei: 1) the presence of a large copulatory opening (atrium) inside the epigastral furrow; 2) part of the female copulatory apparatus is located in the postgastrum; 3) the presence of a permanent mating plug; and 4) the mating plug represents a part of the female copulatory organ.

РЕЗЮМЕ. Переописаны монотипичный род Chedima Simon, 1873, номинативный для подсемейства Chediminae, и его типовой вид C. purpurea Simon, 1873. Впервые приводятся изображения копулятивных органов $C$. purpurea. Морфологическое исследование выявило наличие нескольких признаков, ранее неизвестных либо для Palpimanidae и Entelegynae, либо для отряда Aranei в целом. Сюда относятся: 1) наличие крупного копулятивного отверстия (атриума) в эпигастральной щели; 2) локализация части копулятивных органов самки в постгаструме; 3) наличие стопорного устройства постоянного, а не временного типа; и 4) тот факт, что упомянутое устройство является частью копулятивных органов самки.

\section{Introduction}

The Palpimanidae, or brush-footed spiders, is a minute family with 144 species placed in 18 genera [WSC, 2017]. The family has a rather unusual distribution: the entire Africa and Neotropical Region (north to Cuba) and a vast part of Eurasia (from the Iberian Peninsula to Malaysia) [Platnick, 2014]. All species are restricted to the subtropical and tropical regions. The family is currently divided into three subfamilies: Chediminae Simon, 1893, Palpimaninae Thorell, 1870, and Otiothopinae Platnick, 1975 [Jocqué, DippenaarSchoeman, 2006]. The latter subfamily (with a few exceptions due to misplacement) is restricted to the Neotropics and relatively well investigated; while the two former subfamilies are restricted to the Old World and both have been poorly studied. The nominative type genus of the Chediminae, the monotypic Chedima Simon, 1873, has been never properly described. There are only three published figures devoted to this genus and demonstrating the habitus and the eye group [Simon 1873, 1893]. The copulatory organs of Chedima have been never illustrated.

While studying palpimanids in the Senckenberg Museum (Frankfurt-am-Main) we found two specimens that match the description of Chedima purpurea Simon, 1873 in respect to their habitus, eye pattern and some other characters. Both specimens were collected close to the type locality of $C$. purpurea. Unfortunately, the types of this species are currently unavailable, 
due to having been borrowed long ago and not yet returned (Rollard, pers. comm.). During examination of the female copulatory organ we encountered difficulty in excavation of the epigastral scutum. This was caused by the presence of two interacting structures. One of them was not previously known in the Palpimanidae (a large copulatory opening hidden in the epigastric fold) and another structure (an extension of the posterior wall of the epigastric fold that fits the copulatory opening and serves as a plug) that has been never reported in spiders.

The main aim of this paper is to provide a detail redescription of Chedima purpurea and its uniquely shaped copulatory organs.

\section{Material and methods}

Photographs were taken in dishes of different sizes with a paraffin layer on the bottom. Specimens were photographed using an Olympus Camedia E-520 camera attached to an Olympus SZX16 stereomicroscope and with a SEM JEOL JSM-5200 scanning microscope at the Zoological Museum, University of Turku. Digital images were prepared using the "CombineZP" image stacking software (http://www. hadleyweb.pwp.blueyonder.co.uk/). Illustrations of the female copulative organs were made after maceration in the $20 \%$ potassium hydroxide aqueous solution and exposure for a few minutes in an alcohol/water solution of Chlorazol Black. Lengths of the leg segments were measured on the dorsal side. All measurements are given in millimetres.

Acronyms: MNHN - Musée national d'Histoire naturelle, Paris, France; SMF — Senckenberg Museum, Frankfurt-am-Main, Germany; ZMUT - Zoological Museum, University of Turku, Finland.

Abbreviations: ALE — anterior lateral eyes, ALS anterior lateral spinnerets, AME - anterior median eyes, $A t$ - atrium, $D i$ - diverticulum, $E p$ - epigastrum, $E b-$ base of embolus, $E m$ - embolus, Eo - embolic opening, $L n$ - labial notch, $L p$ - large process of tegulum, $L r-$ lateral "receptacle", $L s$ - lateral scutum, MOQ - median ocular quadrangle, $M p$ - median plate, $M s$ - median scutum, $P a$ - parmula, PLE - posterior lateral eyes, PLS posterior lateral spinnerets, PME - posterior median eyes, PMS - posterior median spinnerets, $P w$ - posterior wall of endogyne, $R e$ - rigid extension of posterior wall of epigastric fold, $S c$ - scopula, $S o$ - spine-like outgrowth of Up, $S p$ - small process of tegulum, $S r-$ sac like receptacle, $S u$ - sulci. $U p$ - upper part of $L p$.

\section{Taxonomic survey}

Family Palpimanidae Thorell, 1870

Subfamily Chediminae Simon, 1893

Chedimeae Simon, 1893: 402.

Chediminae: Jocqué, Dippenaar-Schoeman, 2006: 240; Zonstein, Marusik, 2013: 36.

NOTES. Currently, twelve genera are considered in this subfamily: namely, Badia Roewer, 1961; Boagrius Simon, 1893; Chedima Simon, 1873; Chedimanops Zonstein et Marusik, 2017; Diaphorocellus Simon, 1893; Hybosida Simon, 1898; Hybosidella Zonstein et
Marusik, 2017; Levymanus Zonstein et Marusik, 2013; Sarascelis Simon, 1897; Scelidocteus Simon, 1907; Scelidomachus Pocock, 1899 and Steriphopus Simon, 1898 [Jocqué, Dippenaar-Schoeman, 2006; Zonstein, Marusik, 2013, 2017]. Although Chediminae is the most genus-rich subfamily (12 of 18 known in the family), its species diversity (32 in total) is lower than in the two other subfamilies.

\section{Genus Chedima Simon, 1873}

Chedima Simon, 1873: 151.

TYPE SPECIES: Chedima purpurea Simon, 1873, by monotypy.

DIAGNOSIS. In general appearance, the presence of the numerous cuticle thorns on coxa, femur, patella, tibia and metatarsus I, and structure of the bulb, provided with a long arched tegular process, Chedima resembles the genera Scelidomachus and Scelidocteus (cf. Figs $2 D-E$ and Jézéquel, 1964, figs 2a-b, 4a-b; Zonstein, Marusik, 2013, fig. 4). It can be easily distinguished from them by the abdominal pattern (species of the two other genera have a uniformly coloured abdomen) and by the eye shape and arrangement (in Scelidomachus and Scelidocteus MOQ is subquadrate, in Chedima it is three times as long as broad).

DESCRIPTION. Medium-sized chedimine palpimanids with body length $c a$. $6 \mathrm{~mm}$ in males and females; abdomen with spotted pattern. Carapace with coarsely granulated cuticle, oval in dorsal view. Cephalic part gently raised behind eye area. Thoracic fovea short, deep and longitudinal. Eight eyes. ALE largest and set close to each other (interdistance AME-AME noticeable smaller than their diameter), about 1.3-2 times larger than other eyes. ALE and PLE almost touching each other. Interdistance PME-PME about two times as long as their diameter. Clypeus about two times higher than AME diameter. Chilum inconspicuous. Chelicerae with low lateral mound and stridulatory ridges; cheliceral furrow with few peg teeth. Labium long trapezoidal, anteriorly deeply notched (1/3 of labium length, Fig. 1). Sternum shield-like with fine reticulation; labium about 1.5 times as long as broad at base.

Palps relatively short; legs I-IV long and slender. Leg formula: 1423 (male) or 4123 (female). Coxae I very large, dorsally with numerous tiny thorns. Femur I thick and swollen. Femur, patella and tibia I ventrally with numerous small cuticular thorns, metatarsus I with few large ventral thorns (distalmost of them largest). Tibia and metatarsus I with well-developed prolateral scopula. Leg tarsi scopulate. Claw tufts well-developed. Leg tarsi with two very narrow and weakly dentate claws. Paired claws with 1-2 tiny subapical teeth; on tarsus I they noticeably smaller than on tarsi II-IV.

Abdominal scuta conforming a rather short pedicel tube; dorsal portion of scutum relatively small. Posterior margin of epigastrum Spinneret group medium-sized. Spinneret group set on low mound, inframammillary scutum absent. AMS small, cylindrical, two-segment- 


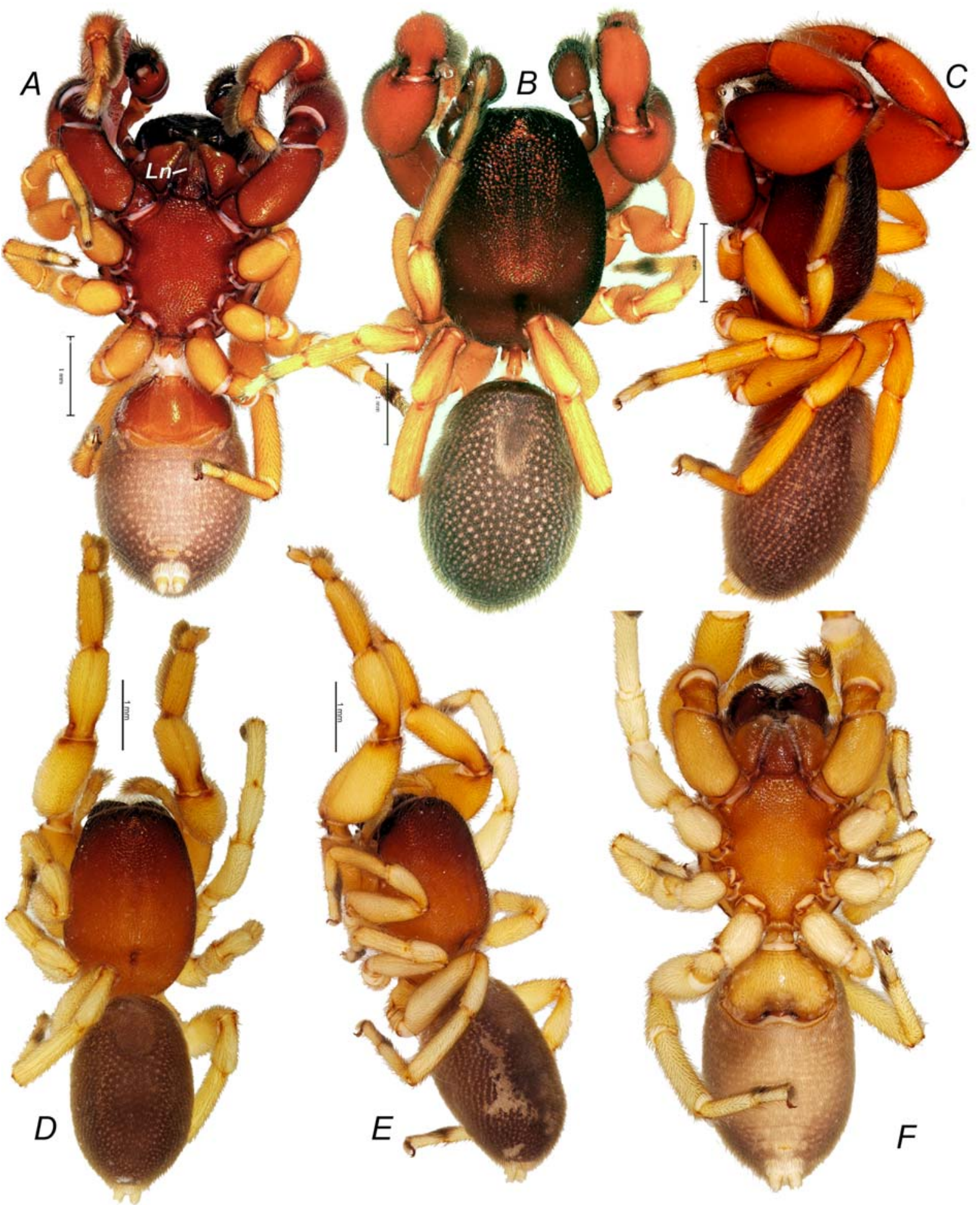

Fig. 1. Chedima purpurea, general appearance of male $(A-C)$ and female $(D-F) . A, F-$ ventral; $B, D-$ dorsal; $C, E-$ lateral. Scale $=1.0 \mathrm{~mm}$. Abbreviation: $L n-$ labial notch.

Рис. 1. Chedima purpurea, внешний вид самца $(A-C)$ и самки $(D-F)$. $A, F-$ вентрально; $B, D-$ дорзально; $C, E-$ сбоку. Масштаб 1,0 мм. Сокращение: $L n-$ вырез нижней губы. 

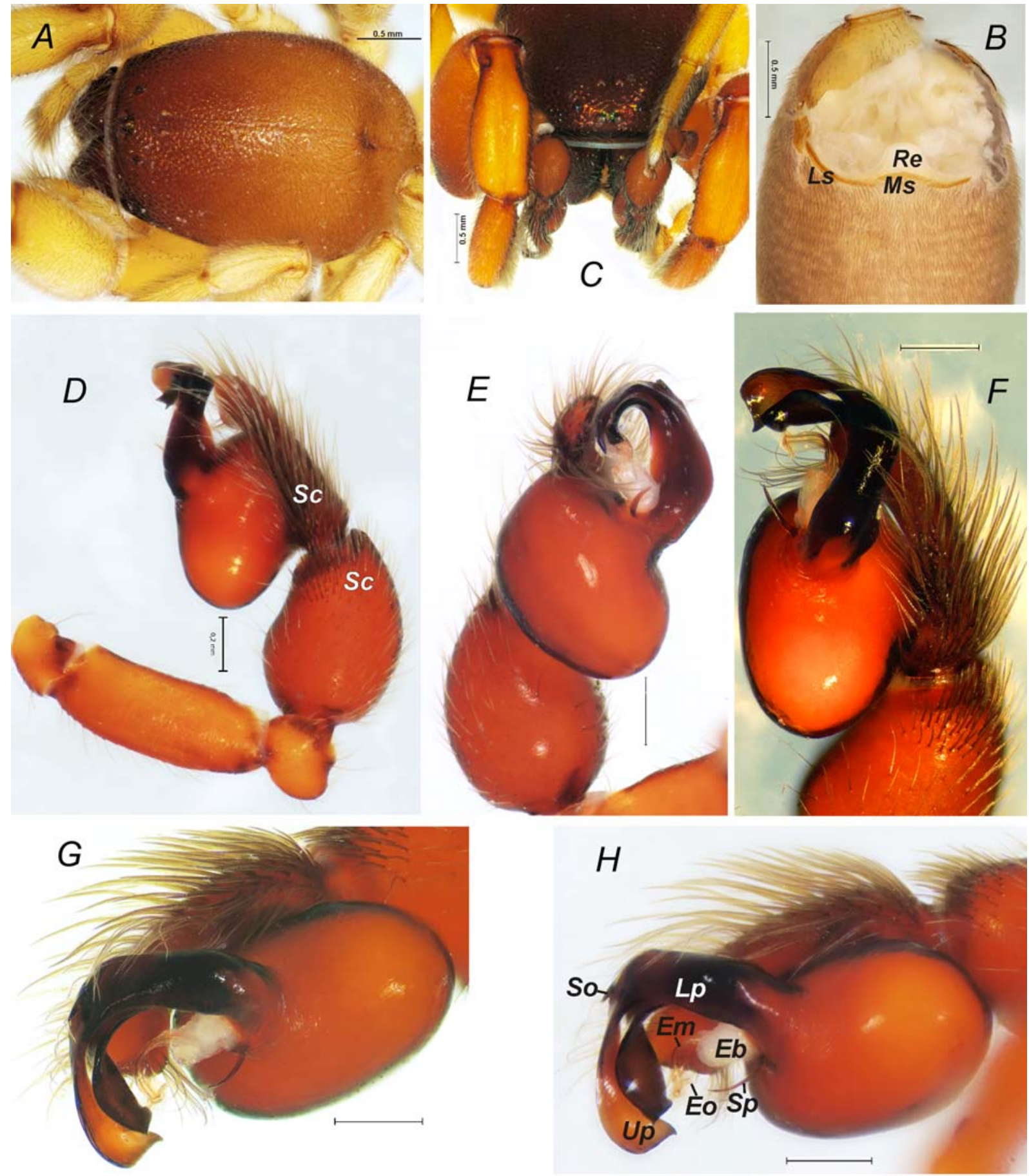

Fig. 2. Chedima purpurea, somatic characters and copulatory organs of female $(A-B)$ and male $(C-H)$. $A-$ prosoma, dorsal; $B-$ abdomen with dissected epigastric scutum, showing rigid extension; $C$ - anterior part of prosoma, dorsal; $D-H$ - male palp, different aspects $(D-$ retrolateral; $E$ - ventro-prolateral; $F-H$ - ventro-retrolateral). Scale bar: $0.2 \mathrm{~mm}$, if not otherwise indicated. Abbreviations: $E b$ - base of embolus; $E m$ - embolus; Eo — embolic opening; $L p$ - large process of tegulum; $L s$ — lateral scutum; $M s$ - median scutum; Re - rigid extension of posterior wall of epigastric fold; $S c$ - scopula; $S o$ - spine like outgrowth of $U p ; S p$ - small process of tegulum; $U p$ - upper part of $L p$.

Рис. 2. Chedima purpurea, соматические признаки и копулятивные органы самки $(A-B)$ и самца $(C-H)$. $A-$ просома, дорзально; $B$ - брюшко с удалённым эпигастральным скутумом, показан вырост постгаструма; $C$ - передняя часть просомы, дорзально; $D-H$ - пальпа самца, разные аспекты ( $D$ - ретролатерально; $E$ - вентро-пролатерально; $F-H$ - ventro-ретролатерально). Масштаб 0,2 мм, если не указано иначе. Сокращения: $E b-$ основание эмболюса; $E m-$ эмболюс; $E o-$ отверстие эболюса; $L p$ - большой вырост теглюма; $L s$ - латеральный скутум; $M s-$ медиальный скутум; Re - жесткий вырост задней стенки эпигастральной щели; $S c$ - скопула; So - шиповидный вырост $U p ; S p$ - маленький вырост тегулюма; $U p$ - верхняя часть $L p$. 

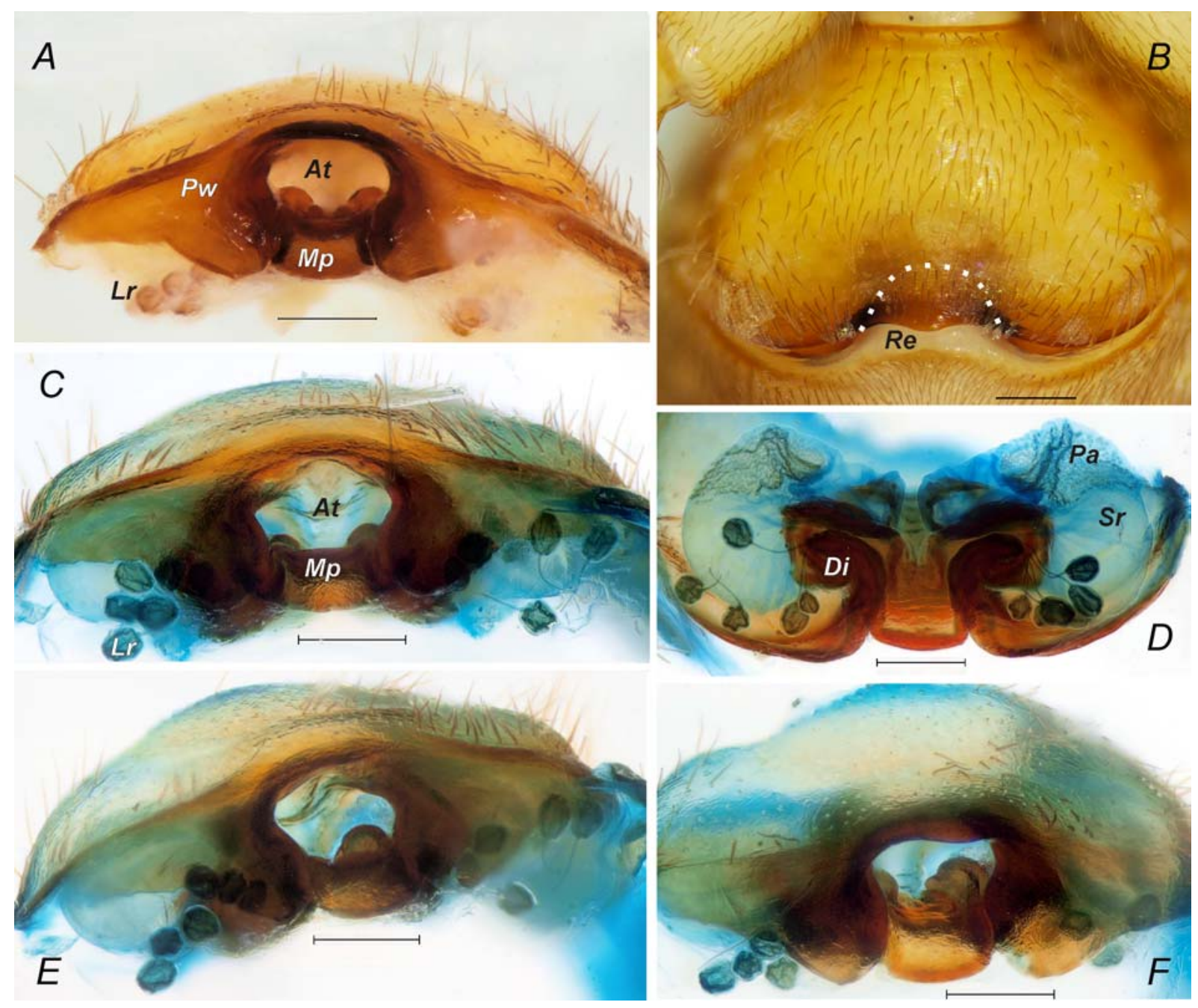

Fig. 3. Chedima purpurea, copulatory organs of the female, before $(A-B)$ and after $(C-F)$ maceration. $A-F-$ different aspects showing atrium: $A, C$ - posterior (caudal); $B-$ ventral; $D-$ dorsal; $E-F-$ posterior-lateral. Scale $=0.2 \mathrm{~mm}$. Abbreviations: $A t-$ atrium; $D i$ - diverticulum; $L r$ - lateral "receptacle"; $M p$ - median plate; $P w$ - posterior wall of endogyne; $R e$ - rigid extension of posterior wall of epigastric fold; $\mathrm{Sr}$ - sac like receptacle.

Рис. 3. Chedima purpurea, копулятивные органы самки, до $(A-B)$ и после $(C-F)$ мацерации. $A-F-$ разный аспекты показывающие атриум: $A, C$ - сзади (каудально); $B$ - вентрально; $D$ - дорзально; $E-F$ - сзади-сбоку. Масштаб 0,2 мм. Сокращения: $A t-$ атриум; $D i$ - вырост; $L r$ - латеральная "рецептакула"; $M p$ - медиальная пластинка; $P w$ - задняя стенка эндогины; Re — жесткий вырост задней стенки эпигастральной щели; $S r$ - мещковидная рецептакула.

ed; PMS and PLS absent at least in males.

Male palp as in Figs $2 D-H$ : coxa and femur not modified; femur subequal in length to patella+tibia; patella wider than long, with dorsal extension; tibia swollen, 1.5 longer than wide, terminal retrolateral part with brush of strong setae (=scopula, Sc); cymbium thin, subequal in length to tibia, with scopula on retrolateral side; bulb oval, with two tegular processes ("conductors") large and small; large process ( $L p)$ complex, subdivided in upper half into two arched parts, upper part $(U p)$ with spine like outgrowth $(S o)$; small process $(S p)$ needle shaped; arched and lamellate embolus $(E m)$ relatively small, weekly sclerotized, transparent, tip with two cylindrical extensions, ventral extension with sperm duct opening $(E o)$; embolus originates from weakly sclerotized sac-like base $(E b)$.

Female copulatory organ as in Figs $2 B, 3$. In ventral view epigastric scutum smooth, without any sigilla-like structures; posterior edge of epigastric scutum bow like, shallowly concave in median part, concave part with shallow rounded extension; posterior edge of epigastric furrow (postgastric area) with three thin scuta, two lateral $(L s)$ and one median $(M s)$, all these scuta almost fused. Dissected copulatory organ (endogyne): epigastric scutum with strongly sclerotized posterior wall $(P w)$ (undocumented in other Palpimanidae), with large copulatory opening $(\mathrm{Co})$ and median plate $(\mathrm{Mp})$ above it; copulatory opening leads to large atrium (At); median plate and lateral walls forms pair of diverticula (Di); each diverticulum bears 6 spherical lateral recep- 
tacles $(L r)$ (sensu Forster and Platnick 1984) with long duct (stem) and one bent membranous sac like receptacle $(S r)$; sac like receptacle with porous area $(P a)$. Posterior wall of epigastric fold with weakly sclerotized but rigid extension $(R e)$ that fills whole copulatory opening and serving as plug.

SPECIES INCLUDED. Only the type species.

NOTE. It is not clear whether the lateral receptacles serve as real receptacles. They are too small to accept all sperm. It is possible that they serve as secretory glands.

\section{Chedima purpurea Simon, 1873}

Figs $1-3$.

Chedima purpurea Simon, 1873: 152, pl. 3, figs 22-23 ( $\sigma^{7}+$; only $q$ habitus and eye field illustrated), $1 \sigma^{7}, 1+$ syntypes from Morocco, collected between Tangier and Fes; deposited in MNHN (borrowed to date by another museum, thus not examined).

Chedima purpurea: Simon, 1893: 404, fig. 364 ( $\$$; only eye field illustrated).

MATERIAL EXAMINED: $1 \overbrace{}^{\top}$ (SMF), MOROCCO: Taza, 30 $\mathrm{km}$ SE Tissa, $34^{\circ} 14^{\prime} \mathrm{N}, 4^{\circ} 27^{\prime} \mathrm{W}, 450 \mathrm{~m}, 25.02 .2004$ (D.W. Wrase); 1 ㅇ (SMF), same area, Had Msila $22 \mathrm{~km} \mathrm{NW} \mathrm{Taza,} 34^{\circ} 31^{\prime} \mathrm{N}$, $4^{\circ} 10^{\prime} \mathrm{W}, 550 \mathrm{~m}, 21.02 .2004$ (D.W. Wrase).

DIAGNOSIS. See diagnosis of the genus above.

DESCRIPTION. Male. Body length 6.10. Colour in alcohol: carapace dark golden-red; chelicerae reddish-brown, palps and legs I intensive reddish-orange; legs II-IV light yellowish-orange; maxillae light red; labium and sternum golden-red (labium slightly darker than sternum); abdomen light chestnut (slighter lighter ventrally) with numerous, dense and uniformly spread small pale yellowish-brown spots.

General appearance as in Figs $1 A-C$. Carapace 2.97 long, 2.03 wide. Eye sizes and interdistances: AME 0.12, ALE 0.09, PLE 0.09, PME 0.07, AME-AME 0.10, AME-ALE 0.17, AME-PME 0.38, ALE-PLE 0.02, PLE-PME 0.23, PME-PME 0.13. Cheliceral furrow with few peg teeth. Leg measurements as shown in Table 1.

Palp: same as for the genus.

Female: Body length 5.85. Colour in alcohol as in male, but with paler coloured carapace, palps and legs I; carapace mostly light red and darkened only in anterior quarter, legs I only slighter darker than legs II-IV.

General appearance as in Figs $1 D-F$. Carapace (Figs 2-3) 2.79 long, 1.88 wide. Eye sizes and interdistances: AME 0.10, ALE 0.07, PLE 0.07, PME 0.07, AMEAME 0.06, AME-ALE 0.17, AME-PME 0.31, ALE-
PLE 0.02, PLE-PME 0.28, PME-PME 0.10. Cheliceral furrow with few peg teeth. Tibia I prolaterally with 3-4 cone spinules. Leg measurements as shown in Table 1 (in parentheses).

Paired claws with 8-9 teeth on tarsi I-II and 5-6 teeth on tarsi III-IV. Unpaired claw on tarsi I-IV sharply curved.

Copulatory organs: same as for the genus.

DISTRIBUTION. Northern Morocco.

\section{Discussion}

A morphological study of Chedima purpurea revealed several features previously unknown in the Palpimanidae, or in the Entelegynae, or within the entire order. These characters are as follows: (1) the presence of a large copulatory opening (atrium) inside the epigastral furrow; (2) a part of the copulatory apparatus is located in the postgastrum; (3) the presence of a permanent mating plug; and (4) this mating plug is an integral part of the female copulatory organ.

1) The Palpimanidae are considered to be entelegyne spiders possessing the secondary haplogyne-type copulative organs [Dippenaar-Schoeman, Jocqué, 1997]. The haplogynes have no separate copulatory opening and the entire palp penetrates into the epigastral furrow in order to inseminate a female. In contrast to the haplogynes, the Entelegynae have copulatory openings located on the ventral surface of the epigyne, with some exceptions when the copulatory opening located inside the epigastral furrow: Liocranidae, Paratus Simon, 1898 (cf. Marusik et al., 2008), or Hersiliidae, Duninia Marusik et Fet, 2009 (cf. Marusik, Fet, 2009). The copulatory openings or fovea have never been documented in Palpimanidae and the process of sperm transfer from the male palp to the endogyne has remained unclear. The current examination of Chedima purpurea revealed the presence of a large atrium located on the front wall of the epigastral fold (Figs $3 \mathrm{~A}$, $C, E-F)$. A similar atrium was found in two species of Diaphorocellus Simon, 1893, another member of Chediminae [Zonstein et al., 2016, fig. 10].

2) With a few exceptions, the female copulatory organs of spiders are located anteriorly from the epigastral fold (=epigastrum) only. However, some spider taxa are known to have the copulatory organs on both sides of the epigastral fold (epi- and postgastrum). A good example of this are the Scytodidae, which feature

Table 1. Chedima purpurea, male and female (in parentheses), leg measurements. Таблица 1. Chedima purpurea, самец и самка (в скобках), промеры ног.

\begin{tabular}{|l|c|c|c|c|c|c|}
\hline & Femur & Patella & Tibia & Metatarsus & Tarsus & Total \\
\hline Palp & $0.86(0.73)$ & $0.32(0.31)$ & $0.72(0.45)$ & - & $0.73(0.42)$ & $2.50(1.91)$ \\
\hline I & $2.05(1.58)$ & $1.65(1.32)$ & $1.36(1.13)$ & $0.56(0.50)$ & $0.51(0.43)$ & $6.13(4.96)$ \\
\hline II & $1.44(1.22)$ & $0.98(0.90)$ & $1.13(0.81)$ & $0.75(0.63)$ & $0.48(0.46)$ & $4.78(4.02)$ \\
\hline III & $1.21(1.07)$ & $0.84(0.65)$ & $0.92(0.78)$ & $0.77(0.57)$ & $0.50(0.45)$ & $4.24(3.52)$ \\
\hline IV & $1.76(1.52)$ & $1.09(0.87)$ & $1.43(1.30)$ & $1.18(1.06)$ & $0.57(0.51)$ & $6.03(5.26)$ \\
\hline
\end{tabular}




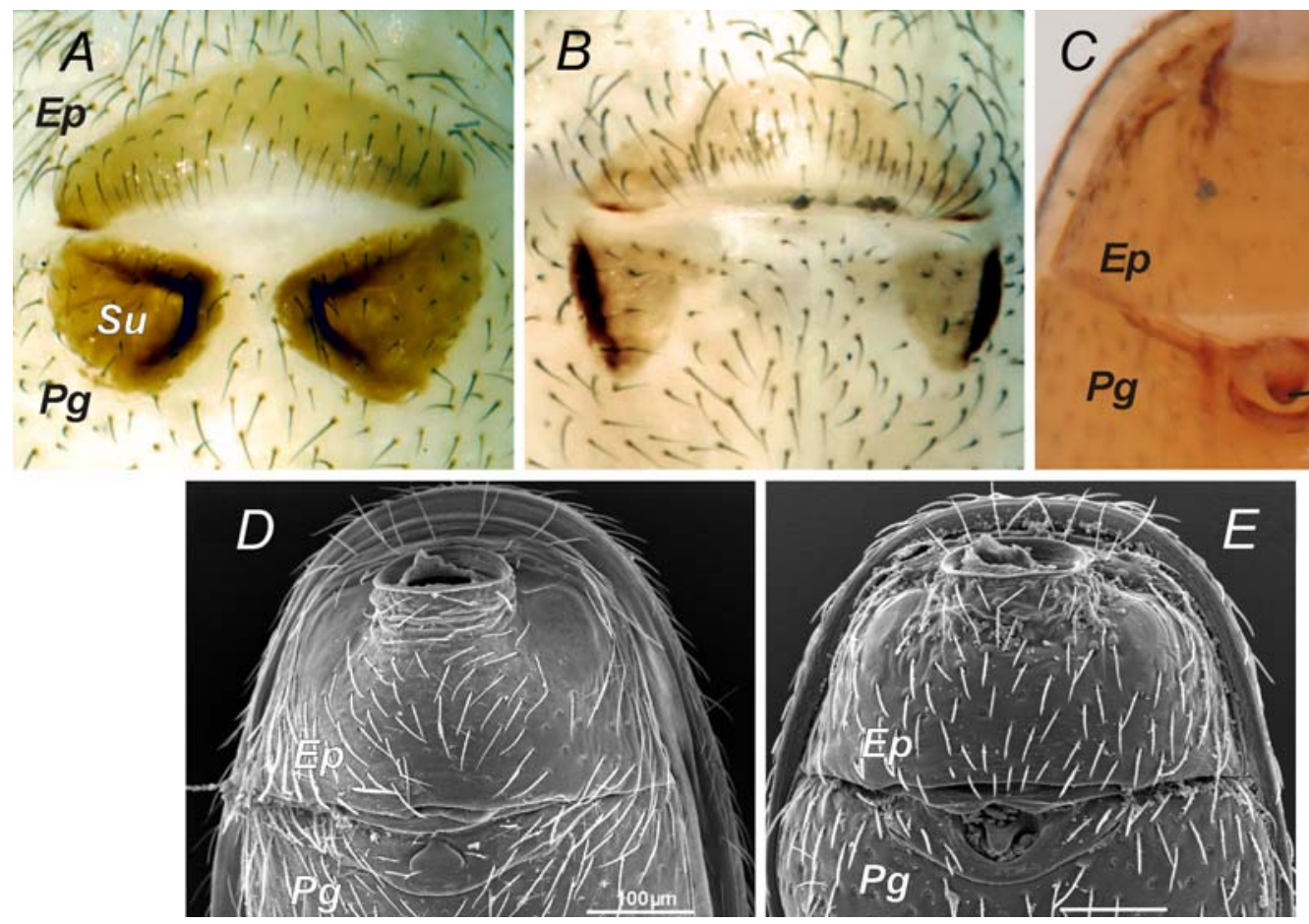

Fig. 4. Females of several spiders with postgastral copulatory structures $(A-B-$ Scytodidae; $C-E-$ Oonopidae). $A-S c y t o d e s$ univittata Simon, 1882; B - S. strandi Spassky, 1941; C, E - Opopaea punctata (O. Pickard-Cambridge, 1872); D — Epectris apicalis Simon, 1893. Abbreviations: $E p$ - epigastrum; $P a$ - parmula; $P g$ - postgastrum; $S u$ - sulci.

Рис. 4. Самки некоторых видов с копулятивными структурами на постгаструме ( $A-B-$ Scytodidae; $C-E-$ Oonopidae). $A-$ Scytodes univittata Simon, 1882; B-S. strandi Spassky, 1941; C, E-Opopaea punctata (O. Pickard-Cambridge, 1872); D - Epectris apicalis Simon, 1893. Сокращения: $E p$ - эпигаструм; $P a$ - пармула; $P g$ - постгаструм; $S u$ - складка.

the endogyne in an epigastral part and a pair of sulci (or the anchoring hole) on the postgastrum (Figs $3 A-$ $B)$. Additional examples can be found in several genera of the Oonopidae, such as Opopaea Simon, 1892, Brignolia Dumitrescu et Georgescu, 1983, Epectris Simon, 1893. Opopaea has a small depression on the postgastral scutum with a knob-like like outgrowth (or parmula) (Figs 23-24). Brignolia has another modification connected with the postgastral scutum: a median depression with a kind of the scape directed posteriorly or anteriorly (cf. Saaristo, 2001: figs 135a-b, 142a). In all the described cases modification on the postgastrum seems to assist during copulation. All known groups with their copulatory organs located on the postgastrum belong to different lineages of haplogyne spiders: Dysderoidea (Oonopidae) and Scytodoidea, and have never previously been documented for the Entelegynae.

3) The presence of a mating (post-mating) plug is common in many entelegyne groups of spiders, but they are all of male origin: e.g. the embolic cup in Araneidae; a broken tip of the embolus in Latrodectus Walckenaer, 1805; an entire palp in some Theridiidae; modified cymbial setae in some Salticidae [GarcilazoCruz, Alvarez-Padilla, 2015]; a tip of the conductor or the paracymbium, or often the bulb secretions (many families) (see Uhl et al., 2010). To date, a pre-mating plug had not been documented in any spider.
4) All the aforementioned types of mating plugs either belong to the broken parts of male palp or anyway are of male origin. Such plugs have never been known from females. Modification of the postgastrum as found in Chedima appears to be a mechanism preventing copulation, and this structure possibly prevents the leaking of sperm when it is placed in the atrium. It is not clear how a weakly sclerotized embolus can penetrate the atrium, but the large process of the tegulum $(L p)$ probably assists to rise the rigid outgrowth (plug) of the postgastrum.

ACKNOWLEDGEMENTS. We thank Peter Jäger and Julia Altmann (SMF) for enabling us to study specimens of $C$. purpurea kept in the spider collection of that museum, Seppo Koponen (Turku, Finland) and Mikhail M. Omelko (Vladivostok Russia) for reviewing manuscript. Naomi Paz (Tel-Aviv University) kindly edited language of the final draft. Special thanks are due to Seppo Koponen for providing us with museum facilities. This study was supported in part by the Israeli Ministry of Absorption.

\section{References}

Dippenaar-Schoeman A.S., Jocqué R. 1997. African Spiders: An Identification Manual // Plant Protection Research Institute Handbook. Vol.9. 392 p. 
Forster R.R., Platnick N.I. 1984. A review of the archaeid spiders and their relatives, with notes on the limits of the superfamily Palpimanoidea (Arachnida, Araneae) // Bulletin of the American Museum of Natural History. Vol.178. P.1-106.

Garcilazo-Cruz U., Alvarez-Padilla F. 2015. Description of a novel mating plug mechanism in spiders and the description of the new species Maeota setastrobilaris (Araneae, Salticidae) // ZooKeys. Vol.509. P.1-12.

Jocqué R., Dippenaar-Schoeman A.S. 2006. Spider Families of the World. Musée Royal de l'Afrique Central. Tervuren. 336 p.

Jézéquel J.-F. 1964. Araignées de la savane de Singrobo (Côte d'Ivoire). II.-Palpimanidae et Zodariidae // Bulletin du Muséum National d'Histoire Naturelle de Paris. T.36. P.326-338.

Marusik Yu.M., Fet V. 2009. A survey of east Palearctic Hersiliola Thorell, 1870 (Araneae, Hersiliidae), with a description of three new genera // ZooKeys. Vol.16. P.75-114.

Marusik Yu.M., Zheng G., Li S.Q. 2008. A review of the genus Paratus Simon (Araneae, Dionycha) // Zootaxa. Vol.1965. P.50-60.

Platnick N.I. 2014. The world spider catalog, version 15. American Museum of Natural History, online at http://research.amnh.org/ entomology/spiders/catalog/index.html
Saaristo M.I. 2001. Dwarf hunting spiders or Oonopidae (Arachni$\mathrm{da}$, Araneae) of the Seychelles // Insect Systematics \& Evolution. Vol.32. P.307-358.

Simon E. 1873. Aranéides nouveaux ou peu connus du midi de l'Europe (2me mémoire) // Mémoires de la Société Royale des Sciences de Liège. T.2. No.5. P.1-174.

Simon E. 1893. Histoire naturelle des araignées. Paris. T.1. P.257488.

Uhl G., Nessler S.H., Schneider J.M. 2010. Mating plugs and genital mutilation in spiders (Araneae) // Genetica. Vol.138. P.75-104.

World Spider Catalog. 2017. World Spider Catalog. Available from: http://wsc.nmbe.ch, version 18.0. (accessed 23.05.2017)

Zonstein S., Marusik Yu.M. 2013. On Levymanus, a remarkable new spider genus from Israel, with notes on the Chediminae (Araneae, Palpimanidae) // ZooKeys. Vol.326. P.27-45.

Zonstein S., Marusik Yu.M. 2017. Descriptions of the two-eyed African spider genera Chedimanops gen. n. and Hybosidella gen. n. (Araneae, Palpimanidae, Chediminae) // African Invertebrates. Vol.58. No.1. P.23-47.

Zonstein S., Marusik Yu.M., Omelko M.M. 2016. Redescription of the type species of Diaphorocellus Simon, 1893 (Araneae: Palpimanidae: Chediminae) // African Invertebrates. Vol.57. No.2. P.93-103.

Responsible editor: K.G. Mikhailov 